\title{
RANCANG BANGUN PEMBAYARAN PAJAK BUMI DAN BANGUNAN PADA KANTOR DESA MEKAR BAHALAT
}

\author{
Anggi Arwansyah ${ }^{1}$, Dedi Suhendro ${ }^{2}$, Muhammad Khaidir ${ }^{3}$ \\ Program Studi Komputerisasi Akuntansi \\ AMIK Tunas Bangsa Pematang Siantar \\ Jl. Jend Sudirman Blok A, No. 1,2 dan, Kota Pematangsiantar, \\ Sumatera Utara \\ anggiarwansyah18@gmail.com 1 \\ Dedi.su@amiktunasbangsa.ac.id ${ }^{2}$ \\ MuhammadKhaidir2804@gmail.com ${ }^{3}$
}

\begin{abstract}
Abstrak
Abstrak - Kemajuan Ilmu Pengetahuan dan Teknologi saat ini sangat berperan penting dalam kehidupan manusia dalam mengerjakan atau menyelesaikan suatu aktivitas perkerjaan sehari-hari, Khususnya dalam Pembayaran Pajak Bumi dan Bangunan pada Desa Mekar Bahalat, yang belum menggunakan sistem dalam melakukan pembayaran pajak bumi dan bagunan disini penulis ingin mengembangkan sistem pembayaran pajak pada kantor tersebut menjadi terkomputerisasi dengan Bahasa Pemrograman Microsoft Visual Studio 2010 dengan database MySql. Oleh karena itu dengan adanya sistem yang dirancang oleh penulis dapat meminimalisir kesalahan yang terjadi dalam pembayaran Pajak dan dapat mengoptimalkan secara efektif dan efisien.
\end{abstract}

Kata Kunci : Microsoft Visual Studio 2010, MySql, Pembayaran Pajak

\section{Pendahuluan}

Seiring dengan perkembangan Ilmu Pengetahuan dan Teknologi khususnya dalam bidang komputer, setiap generasi baru harus mampu menyesuaikan dan mengembangkan diri terhadap lingkungan yang dinamis dengan cara membekali diri dengan kompetensi dan pengetahuan. Pengolahan data secara komputerisasi sangat penting dilakukan karena memberikan 
kontribusi dalam peningkatan kinerja instansi atau perusahaan. Untuk menunjang sistem pengolahan data berbasis komputerisasi perlu didukung dengan sumber daya manusia yang kompeten dan fasilitas yang memadai.

Pada Kantor Desa Mekar Bahalat khususnya pada sistem pembayaran pajak bumi dan bangunan belum menggunakan sistem. Pencatatan pembayaran dilakukan dengan Microsoft Office Word. Pencatatan dengan metode ini terbukti tidak efektif dan efisien, menimbulkan redudansi (data ganda), data tidak berurutan, data tidak akurat, serta menyulitkan dalam pencarian data dimana pegawai harus mencari data dalam filling cabinet dan storage disk bila suatu saat data dibutuhkan kembali.

\section{Defenisi Sistem}

Menurut (Suhendro,2016) sistem informasi meyakini bahwa menggunakan sistem akan membantu dalam meningkatkan kinerjanya.

\section{Defenisi Pembayaran}

Pembayaran dapat diartikan sebagai salah satu kegiatan atau usaha untuk membantu, melayani, mengarahkan atau mengatur semua kegiatan di dalam mencapai suatu tujuan.karena pembayaran merupakan unsur penting bagi sebuah instansi maka di perlukan suatu sistem yang dapat mengelola sistem pembayaran secara baik (Ashari,2014).

\section{Defenisi Pajak}

Pajak dapat didefinisikan sebagai suatu pungutan yang merupakan hak pemerintah, pungutan tersebut didasarkan pada undang-undang serta dapat dipaksakan kepada subbjek pajak dengan tidak ada balas jasa yang langsung dapat ditunjukkan penggunaannya (Sasana,2005).

\section{Defenisi Pajak Bumi dan Bagunan}

Pajak Bumi dan Bangunan (PBB) adalah pajak negara yang bersifat kebendaan, sebagaimana dimaksud dalam UU No. 12 Tahun 1994. PBB dimaksudkan untuk menyederhanakan 
peraturan pajak yang lama, yang belum mempunyai dasar hukum yang kuat (Sasana, 2005).

\section{Metode Penelitian}

Dalam penelitian ini, peneliti menggunakan beberapa metode dalam mengumpulkan data yaitu :

A. Rancangan Menggunakan Data Flow Diagram Level 0

Rancangan proses dimodelkan dengan Data Flow Diagram (DFD). Perancangan DFD merupakan hal yang harus dilakukan karena dengan melihat DFD maka kita akan mengetahui arus data yang mengalir dalam suatu sistem dan mengimplementasikannya pada sebuah database. Dapat dilihat pada gambar 1.

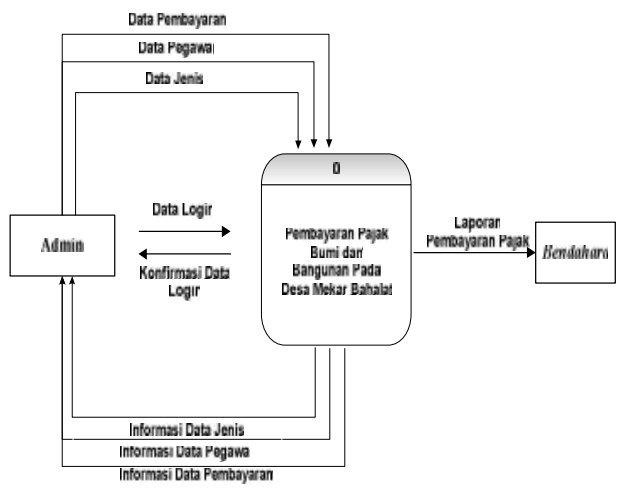

Gambar 1. DFD Level 0

B. Mengunakan Entity Relationship Diagram (ERD)

Bentuk ERD (Entity Relational Diagram) dari data Sistem Pembayaran Pajak Bumi dan Bangunan Pada Desa Mekar Bahalat diperlihatkan pada gambar 2. 


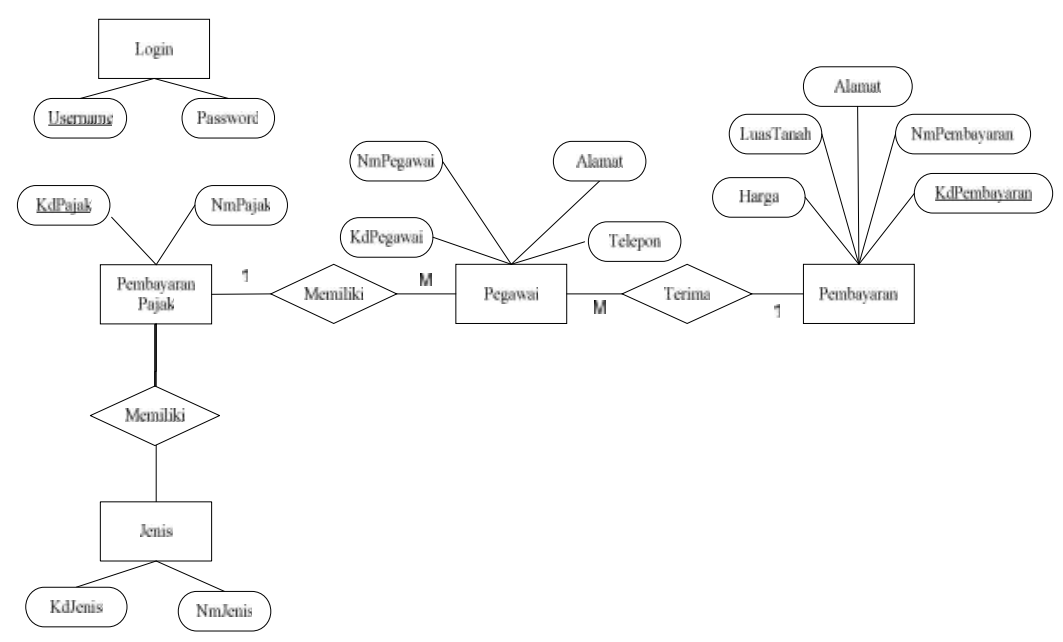

\section{Gambar 2. Entity Relatinal Diagram}

C. Relasi Antar Tabel (RAT)

RAT berguna sebagai gambaran hubungan antara tabel dimana tabel yang mempunyai relasi dapat saling berkomunikasi. Relasi antar tabel dapat dilihat pada gambar 3.

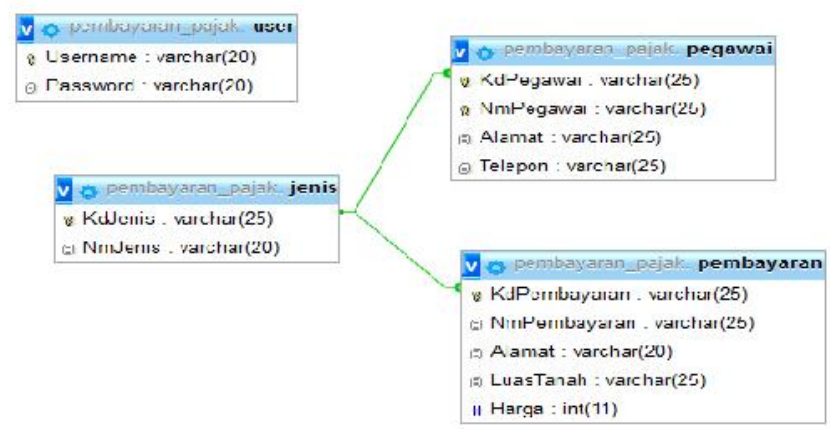

Gambar 3. Relasi Antar Tabel 


\section{a. Subjek Pajak Bumi dan Bangunan}

Subjek pajak adalah mereka (orang atau badan) yang diwajibkan untuk memenuhi kewajiban melunasi pajak bumi dan bangunan, mereka ini adalah:

1. Yang mempunyai hak atas bumi atau tanah

2. Yang memperoleh mafaat atas bumi atau tanah

3. Yang memiliki atau menguaasai atas bangunan

4. Yang memperoleh manfaat atas bangunan.

Yang dimaksud dengan orang adalah orang pribadi atau perseorangan. Sedangkan badan adalah badan usaha dengan nama atau dalam bentuk apapun, termasuk yang berbentuk: Perseroan Terbatas, Perseroan, Komanditer, Badan Usaha Milik Negara (BUMN) dan Badan Usaha Milik Daerah (BUMD) dengan nama dan dalam bentuk apapun. Persekutuan, Firma, Kongsi. Koperasi, Yayasan, atau Organisasi yang sejenis. Lembaga, Dana Pensiun, Bentuk Usaha Tetap (BUT) (Sidharta \& Wati, 2015).

\section{b. Objek Pajak Bumi dan Bangunan}

Yang diamksud dengan objek pajak adalah suatu barang atau benda yang menjadi objek pengenaan pajak. Yang menjadi objek pajak adalah: Bumi, atau yang sehari-hari disebut 'tanah" Dan / atau bangunan yang terletak di atas tanah tersebut (Sidharta \& Wati, 2015).

c. Sektor pengenaan Pajak Bumi dan Bangnnan Untuk mempermudah pelaksanannya, administrasi PBB mengelompokkan objek pajak berdasarkan karakteristiknya dalam beberapa sektor yaitu pedesaan, perkotaan, perhutanan dan pertambangan.

1. Sektor pedesaan, adalah objek PBB dalam satu wilayah yang memiliki ciri-ciri pedesaan, seperti: sawah, ladang, empang tradisional, dan lainlainnya.

2. Sektor Perkotaan, adalah objek PBB dalam suatu wilayah yang memiliki ciri-ciri suatu daerah pekotaan, seperti: pemukiman penduduk yang memiliki fasilitas perkotaan, 
real estate, komplek pertokoan, industri, perdagangan, dan jasa.

3. Sektor Perkebunan, adalah objek PBB yang diusahakan dalam bidang budidaya perkebunan, baik yang diusahakan oleh Badan Usaha Milik Negara/Daerah maupun swasta.

4. Sektor Kehutanan, adalah objek PBB dihidang usaha ynag menghasilkan komoditas hasil hutan, seperti: kayu tebang, rotan, dammar, dan lain- lainnya.

5. Sektor Pertambangan, adalah tambang seperti: emas, batubara, minyak dan gas bumi dan lain-lain.

Tarif dan Cara Penghitungan Pajak Bumi dan Bangunan Berdasarkan pasal 5 Undang-undang No. 12 Tahun 1994 menerapkan tarif Proposional tunggal terhadap Pajak Bumi dan Bangunan, yaitu 0.5 \% (nol koma lima persen) dari nilai jual objek pajak.Tarif ini berlaku untuk semua jenis objek pajak. Hal ini menunjukan bahwa tarif pajak bumi dan bangunan di Indonesia cukup rendah. Besarnya pajak yang terutang dapat dihitung dengan cara:

$$
\begin{aligned}
& \text { PBB }=\text { Tarif pajak } x \text { NJKP } \\
& \quad=0.5 \% \times \text { ( persentase NJKP } \times \text { (NJOP }- \text { NJOPTKP) } \\
& \text { NJOP }=\text { (NJOP Bumi + NJOP Bangunan) }- \text { NJOPTKP }
\end{aligned}
$$

Keterangan :

- NJKP (Nilai Jual Kena Pajak)

- NJOP (Nilai Jual Objek Pajak)

- NJOPTKP (Nilai Jual Objek Pajak Tidak Kena Pajak)

Dasar pengenaan pajak adalah Nilai Jual Objek Pajak (NJOP), yaitu pada harga rata-rata yang diperoleh dari transaksi jual beli yang terjadi secara wajar, dan bilamana tidak terdapat transaksi jual beli, NJOP ditentukan melalui perbandingan harga dengan objek lain yang sejenis atau nilai perolehan baru, atau NJOP pengganti. Adapun untuk dasar penghitungan pajak adalah Nilai 
Jual Kena Pajak yang ditetapkan serendah-rendahnya 20\% dan setinggi- tingginya $100 \%$ dari NJOP.

Sesuai dengan Peraturan Pemerintah No. 16 Tahun 2000, hasil penerimaan Pajak Bumi dan Bangunan merupakan penerimaan negara. Hasil penerimaan PBB tersebut dibagi untuk Pemerintah Pusat dan Pemerintah Daerah dengan imbangan sebagai berikut:

1. $10 \%$ dibagikan untuk Pemerintah Pusat dengan alokasi pembagian:

- 65\% dibagikan secara merata untuk Daerah Kabupaten/Kota.

- 35\% diberikan sebagai insentif untuk Daerah Kabupaten/Kota yang realisasi penerimaan Pajak Bumi dan Bangunan untuk sector pedesaan dan perkotaan pada tahun anggaran sebelumnya mencapai/melampaui rencana penerimaan yang ditetapkan.

2. $90 \%$ dibagikan untuk Pemerintah Daerah dengan alokasi pembagian:

- $16,2 \%$ dibagikan untuk Provinsi

- $64,8 \%$ dibagikan untuk Kabupaten/Kota

- $9 \%$ sebagai biaya pungut

Tata Cara Pembayaran PBB 1) Pajak yang terutang berdasarkan SPPT harus dilunasi selambat- lambatnya 6 (enam) bulan sejak tanggal diterimanya SPPT oleh wajib pajak. 2) Pajak yang terutang berdasarkan SKP harus dilunasi selambat-lambatnya 1 (satu) bulan sejak tanggal diterimanya SKP oleh wajib pajak. 3) Pajak yang terutang yang pada saat jatuh tempo pembayarannya tidak dibayar, dikarenakan denda administrasi sebesar 2\% sebulan, yang dihitung dari saat jatuh tempo sampai dengan hari pembayaran, untuk jangka waktu paling lama 24 bulan. 4) Denda administrasi sebagaimana dimaksud dalam no. 3 di atas, ditambah dengan utang pajak yang belum atau kurang bayar ditagih dengan STP (Surat Tagihan Pajak) yang harus dilunasi selambatlambatnya 1 (satu) bulan sejak tanggal diterimanya STP oleh wajib pajak (Sidharta \& Wati, 2015). 


\section{d. Kebijakan Instansi terhadap Sistem Informasi Pajak Bumi dan Bangunan}

- Petugas administrasi pajak melakukan Perhitungan PBB. Membuat laporan,dan mencetak daftar bukti pembayaran pajak.

- Tarif pijak yang digunakan adalah tarif pajak berdasarkan ketentuan Undang-Undang Pajak Bumi dan Bangunan.

- NJOPTKP (Nilai Jual Objek Pajak Tidak Kena Pajak)

- Wajib pajak adalah semua warga yang mempunyai hak atas tanah dan bangunan

- Potongan Pajak bumi dan bangunan ditetapkan sebesar $0.5 \%$, berdasakan undang- undang no 12 tahun 1985 pasal 5 .

- Surat Pemberitahuan Pajak Terutang (SPPT) diberikan kepada wajib pajak untuk memberitahukan besarnya pajak bumi dan bangunan yang harus dibayar oleh wajib pajak.

- Bagi hasil pajak bumi dan bangunan sebesar 9\% (sembilan persen) berdasarkan ketentuan Pasal 9 peraturan pemerintah No. 55 Tahun 2005.

- Jika mempunyai lebih dari satu objek pajak, yang dikenakan NJOPTKP hanya satu objek pajak yaitu yang nilainya paling tinggi.

- Pemotongan untuk wajib pajak yang mempunyi objek pajak bumi dan bangunan lebih dari satu objek pajak yaitu Rp. 12.000.000.- diambil dari nilai jual objek pajak paling tinggi.

Desa merupakan kesatuan masyarakat hukum yang memiliki batas-batas wilayah yang berwenang untuk mengatur dan mengurus kepentingan masyarakat setempat, berdasarkan asalusul dan adat istiadat setempat yang diakui dandihormati dalam sistem pemerintah Negara kesatuan republik Indonesia. Dalam kegiatan pemungutan pajak bumi dan bangunan di desa, wajib pajak selain harus membayar kewajibannya dalam memenuhi pajak bumi dan bangunan wajib pajak pun harus membayar urunan desa yang merupakan pembebanan (Sidharta \& Wati, 2015). 


\section{Jumlah wajib pajak}

Pertumbuhan penduduk merupakan unsur penting yang dapat memacu pertumbuhan ekonomi suatu wilayah. Penduduk yang besar akan menggerakkan berbagai kegiatan ekonomi dan merangsang tingkat output atau produksi agregat yang lebih tinggi, dan pada alchimya akan meningkatkan pertumbuhan ekonomi yang didorong oleh pendapatan nasional. Insukindro (1.994) menyatakan bahwa peningkatan pendapatan nasional akan menaikkan NJOP, sehingga semakin tinggi beban PBB yang harus ditanggung oleh wajib pajak. Kenaikan NJOP juga dapat menciptakan wajib pajak-wajib pajak baru, di mana masyarakat yang sebelumnya tidak ditetapkan sebagai wajib pajak pada akhirnya menjadi wajib pajak barn. Oleh sebab itu, Insukindro menyimpulkan bahwa pertumbuhan jumlah wajib pajak berpengaruh positif dalam meningkatkan penerimaan PBB. Dengan penjelasan tersebut nampak jelas bahwa pertumbuhan penduduk bila ditangani secara serius akan menambah jumlah wajib pajak yang membayar pajak (Sasana, 2005).

\section{Jumlah luas lahan}

Sebagaimana tercantum dalam pasal 1 UU Pajak Bumi dan Bangunan, yang dimaksud dengan bumi adalah permukaan bumi, (perairan) dan tubuh bumi yang berada di bawahnya. Permukaan bumi itu sebetulnya tidak lain daripada tanah. Jadi yang menjadi objek PBB itu adalah tanah (perairan) dan tubuh bumi. Untuk memudahkan penghitungan PBB yang terutang, tanah perlu diklasifikasikin Yang dimaksud dengan klasifikasi tanah adalah pengelompokkan tanah menurut nilai jualnya, dan memperhatikan faktor-faktor sebagai berikut: a) letak tanah, b) peruntukan tanah, c) pemanfaatan, d) luas lahan / bumi, e) kesuburan atau hasil tanah, f) adanya irigasi atau tidak dan lain sebagainya.

\section{Jumlah bangunan}

Bangunan yang juga dijadikan objek PBB adalah konstruksi teknik yang ditanam atau dilekatkan secara tetap pada tanah (dan / atau perairan), yang diperuntukkan sebagai tempat tinggal atau tempat berusaha atau tempat yang dapat diusahakan. Dalam 
menentukan klasifikasi bangunan diperhatikan faktor-faktor sebagai berikut : a) bahan yang digunakan, b) rekayasa, c) letak, d) kondisi lingkungan dan lain-lain. Sedangkan bangunan dapat dikategorikan dalam : a. Bangunan beton, bangunan bertingkat / susun $b$. Bangunan terbuat dari batu c. Bangunan terbuat dari kayu d. Bangunan semi permanen, dan sebagainya.

\section{Hasil dan Pembahasan}

Pembangunan form pada tulisan ini dibuat dengan bahasa pemrograman Visual Basic .Net 2010. Sistem yang sudah dirancang selanjutnya akan diteruskan ke tahap pengimplementasian sistem. Berisikan hasil atau tampilan dari menu, halaman masukan(Input sistem) dan laporan (Output sistem).

\section{Form Login}

Fungsi Login untuk pengguna dapat masuk dan mengakses program setelah dilakukan validasi yang biasanya berupa username dan password.

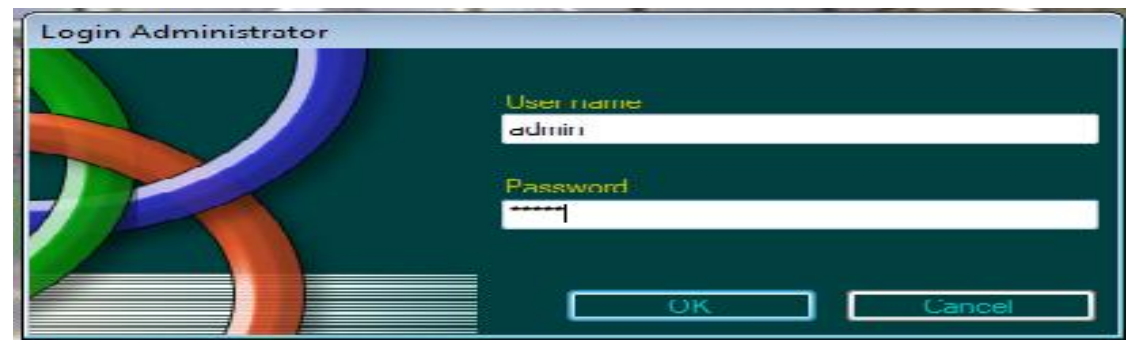

Gambar 4. From Login

Gambar diatas merupakan form login password, password yang dimasukan minimal 5 karakter. Setelah itu pilih Ok untuk melanjutkan.

\section{Masukan Masukan (input)}

Dibawah ini adalah gambaran dari hasil masukan (input) Sistem Pembayaran Pajak Bumi dan Bangunan Desa Mekar Bahalat. 
KANTOR DESA MEKAR BAHALAT

HUTA BAHALAT I

Laporan Pembayaran Pajak Tanah dan Bangunan

\begin{tabular}{|c|c|c|c|c|}
\hline NAMA & ALAMAT & $\begin{array}{l}\text { LUAS } \\
\text { T.AHAN }\end{array}$ & $\begin{array}{l}\text { NILAI } \\
\text { PAJAK }\end{array}$ & TOTAL \\
\hline $\mathrm{xxxxx}$ & $\mathrm{xxxxx}$ & $\operatorname{xxxxx}$ & $\mathrm{xxxxx}$ & $\mathrm{xxxxx}$ \\
\hline $\mathrm{x} \times \mathrm{xx}$ & $\mathrm{x} \times \mathrm{xx} \mathrm{x}$ & $\operatorname{xx} \times x x$ & $\operatorname{xx} \times x \times$ & $\mathrm{x} \times \mathrm{xx}$ \\
\hline $\mathrm{xxxxx}$ & $\mathrm{xxxxx}$ & $\operatorname{xxxxx}$ & $\mathrm{xxxxx}$ & $\mathrm{xxxxx}$ \\
\hline $\mathrm{xxxXx}$ & $\mathrm{xxxxx}$ & $\mathrm{xxXXX}$ & $\mathrm{xxxxx}$ & $\mathrm{xxxxx}$ \\
\hline
\end{tabular}

Gambar 5. Form Rancangan Masukan

\section{Rancangan Keluaran (Output)}

Dibawah ini adalah gambaran dari hasil keluaran (output) Sistem Pembayaran Pajak Bumi dan Bangunan Desa Mekar Bahalat.

KANTOR DESA MEKAR BAHALAT

HUTA BAHALAT I

Laporan Pembayaran Pajak Tanah dan Bangunan

\begin{tabular}{|c|c|c|c|c|}
\hline NAMA & ALAMAT & $\begin{array}{l}\text { LUAS } \\
\text { T.AHAN }\end{array}$ & $\begin{array}{l}\text { NILAI } \\
\text { PATAK }\end{array}$ & TOTAL \\
\hline $\mathrm{xxxxx}$ & $\mathrm{xxkxx}$ & $\mathrm{xxxxx}$ & $\mathrm{xxxxx}$ & $\mathrm{xxxxx}$ \\
\hline $\operatorname{xxxxx}$ & $\mathrm{x} \times \mathrm{x} \times \mathrm{x}$ & $\mathrm{xx} \times \mathrm{xx}$ & $\mathrm{x} \times \mathrm{x} \times \mathrm{xx}$ & $\operatorname{xx} \times x \times$ \\
\hline $\mathrm{xxxxx}$ & $\mathrm{xxxxx}$ & $\mathrm{xxxxx}$ & $\mathrm{xxxxx}$ & $\mathrm{xxxxx}$ \\
\hline $\mathrm{xxxxx}$ & $\mathrm{xxxxx}$ & $\mathrm{xxxxx}$ & $\mathrm{xxxxx}$ & $\mathrm{xxxxx}$ \\
\hline
\end{tabular}

Gambar 6. Form Rancangan Keluaran

\section{Kesimpulan}

Dengan adanya sistem yang telah dibuat oleh penulis dapat membantu para pegawai (staff) dalam melakukan transaksi Pembayaran Pajak agar lebih terorganisir dan lebih baik dalam melakukan trasnsaksi dan memberikan keuntungan bagi para staff dalam melakukan pembayaran pajak. Sistem ini hanya dibuat pada Kantor Lurah Desa Mekar Bahalat. 


\section{Daftar Pustaka}

Ashari, A. (2014). Sistem Informasi Pembayaran Sumbangan Pembinaan Pendidikan (SPP) pada Sekolah Menengah Atas Negeri 2 Pacitan. Indonesian Journal on Networking and Security, 3(3), 65-70.

Sasana, H. (2005). Analisis Faktor-Faktor yang Mempengaruhi Penerimaan Pajak Bumi dan Bangunan (PBB) (Studi Kasus Kabupaten Banyumas). Dinamika Pembangunan, 2, 19-29.

Sidharta, I., \& Wati, M. (2015). Perancangan dan Implementasi Sistem Informasi Urunan Desa (URDES) Berdasarkan Pada Pajak Bumi Dan Bangunan. Jurnal Computech $\mathcal{E}$ Bisnis, 9(2), 95-107.

Suhendro, D. (2016). Pengaruh Kualitas Sistem, Kualitas Informasi, Kualitas Pelayanan Dan Ekspektasi Kinerja Terhadap Kepuasan Pengguna Dalam Penerapan Sistem Teknologi Informasi Pada Koperasi Di Kota Pematangsiantar. Jurasik, 1(1), 33-40. 